\title{
Extended nitric oxide measurements in exhaled air of cystic fibrosis and healthy adults
}

\author{
Hofer, M ; Mueller, L ; Rechsteiner, T ; Benden, C ; Boehler, A
}

\begin{abstract}
In cystic fibrosis ( $\mathrm{CF}$ ) lung disease, exhaled nitric oxide (FeNO) is not raised, but rather is normal or even decreased when measured at a single expiratory flow. FeNO measurements at several flow rates allow differentiation between alveolar and bronchial nitric oxide (NO) production. Extended FeNO measurements therefore should be useful to localize the FeNO deficit in CF airways. FeNO was measured in stable CF adults with moderate lung disease and in healthy controls. Bronchial NO fluxes $(\mathrm{J}(\mathrm{NO}, \mathrm{Br}))$ and alveolar $\mathrm{NO}$ concentrations $(\mathrm{C}(\mathrm{Alv}))$ were calculated from FeNO measurements at flow rates of 100, 150 and $200 \mathrm{ml} / \mathrm{s}$ using a method previously described. Thirty-two adults were included in the study, 12 of whom had CF. CF adults had significantly lower FeNO values at all flow rates. The median $\mathrm{J}(\mathrm{NO}, \mathrm{Br})$ was significantly lower in $\mathrm{CF}$ adults than in healthy controls $[0.31 \mathrm{nl} / \mathrm{s}$ ( range $=0.11$ $0.63)$ vs. $0.70 \mathrm{nl} / \mathrm{s}(0.27-3.52) ; \mathrm{P}<0.001]$, while the median $\mathrm{C}(\mathrm{Alv})$ was similar in both groups $[1.7 \mathrm{ppb}$ (0.3-3.9) vs. $1.2(0.1-5.2)]$. Pulmonary NO exchange did not differ significantly between subgroups of $\mathrm{CF}$ patients with and without chronic Pseudomonas aeruginosa infection. No significant correlation was detectable between $\mathrm{FEV}(1) / \mathrm{VC}$ and $\mathrm{J}(\mathrm{NO}, \mathrm{Br})$ and $\mathrm{C}(\mathrm{Alv})$, respectively. Extended FeNO measurements can separate alveolar and bronchial $\mathrm{NO}$ outputs in $\mathrm{CF}$ adults. The lower FeNO in adults with moderate to severe CF lung disease is likely to be the result of lower bronchial NO output.
\end{abstract}

DOI: https://doi.org/10.1007/s00408-009-9160-8

Posted at the Zurich Open Repository and Archive, University of Zurich ZORA URL: https://doi.org/10.5167/uzh-31370

Journal Article

Published Version

Originally published at:

Hofer, M; Mueller, L; Rechsteiner, T; Benden, C; Boehler, A (2009). Extended nitric oxide measurements in exhaled air of cystic fibrosis and healthy adults. Lung, 187:307-313.

DOI: https://doi.org/10.1007/s00408-009-9160-8 


\title{
Extended Nitric Oxide Measurements in Exhaled Air of Cystic Fibrosis and Healthy Adults
}

\author{
Markus Hofer · Luzia Mueller • Thomas Rechsteiner • \\ Christian Benden · Annette Boehler
}

Received: 4 April 2009/Accepted: 5 July 2009/Published online: 8 August 2009

(C) Springer Science+Business Media, LLC 2009

\begin{abstract}
In cystic fibrosis (CF) lung disease, exhaled nitric oxide (FeNO) is not raised, but rather is normal or even decreased when measured at a single expiratory flow. FeNO measurements at several flow rates allow differentiation between alveolar and bronchial nitric oxide (NO) production. Extended FeNO measurements therefore should be useful to localize the FeNO deficit in CF airways. FeNO was measured in stable $\mathrm{CF}$ adults with moderate lung disease and in healthy controls. Bronchial NO fluxes $\left(\mathrm{J}_{\mathrm{NO}, \mathrm{Br}}\right)$ and alveolar NO concentrations $\left(\mathrm{C}_{\mathrm{Alv}}\right)$ were calculated from FeNO measurements at flow rates of 100, 150 and $200 \mathrm{ml} / \mathrm{s}$ using a method previously described. Thirtytwo adults were included in the study, 12 of whom had CF. $\mathrm{CF}$ adults had significantly lower FeNO values at all flow rates. The median $\mathrm{J}_{\mathrm{NO}, \mathrm{Br}}$ was significantly lower in $\mathrm{CF}$ adults than in healthy controls $[0.31 \mathrm{nl} / \mathrm{s}$ (range $=0.11-$ $0.63)$ vs. $0.70 \mathrm{nl} / \mathrm{s}(0.27-3.52) ; P<0.001]$, while the median $\mathrm{C}_{\mathrm{Alv}}$ was similar in both groups [1.7 ppb (0.3-3.9) vs. $1.2(0.1-5.2)]$. Pulmonary NO exchange did not differ significantly between subgroups of $\mathrm{CF}$ patients with and without chronic Pseudomonas aeruginosa infection. No significant correlation was detectable between $\mathrm{FEV}_{1} / \mathrm{VC}$ and $\mathrm{J}_{\mathrm{NO}, \mathrm{Br}}$ and $\mathrm{C}_{\mathrm{Alv}}$, respectively. Extended FeNO measurements can separate alveolar and bronchial NO outputs in $\mathrm{CF}$ adults. The lower FeNO in adults with moderate to severe CF lung disease is likely to be the result of lower bronchial NO output.
\end{abstract}

M. Hofer · L. Mueller · T. Rechsteiner · C. Benden .

A. Boehler $(\bowtie)$

Division of Pulmonary Medicine, University Hospital Zurich,

Raemistr 100, 8091 Zurich, Switzerland

e-mail: capybara@compuserve.com
Keywords Cystic fibrosis - Adults - Inflammation · Nitric oxide

\section{Introduction}

Nitric oxide (NO), an important signalling mediator in many organ systems, is synthesized from L-arginine by nitric oxide synthetase (NOS), which exists in two constitutive (cNOS) and one inducible (iNOS) isoform. The constitutive isoforms are localized in airway nerves and in bronchial epithelium, in type II alveolar epithelial cells, and in endothelial cells of pulmonary blood vessels, where they synthesize low amounts of NO for regulatory purposes [1]. On the other hand, iNOS releases large quantities of NO on induction by proinflammatory cytokines. Inducible NOS immunoreactivity has been shown in many cell types such as neutrophils, eosinophils, macrophages, type II alveolar epithelial cells, airway epithelial cells, mast cells, fibroblasts, endothelial cells, and airway and vascular smooth muscle cells [2]. Thus, it is not surprising that NO serves diverse physiological and cellular functions in the lungs. The measurement of fractional NO concentrations in exhaled air (FeNO) has been utilized to monitor various conditions of the respiratory tract in health and disease [2-4]. In inflammatory lung disease such as asthma, FeNO has been found to be a useful noninvasive surrogate marker of airway inflammation $[5,6]$.

In cystic fibrosis (CF) airways disease, characterized by neutrophilic airway inflammation and chronic airway infection, nasal and lower-airway FeNO is not raised, but rather is normal or even decreased when measured at a single expiratory flow [7-10]. Unfortunately, the use of constant flow exercises does not allow differentiation if the endogenous NO production originates in the proximal or peripheral 
airways of the lungs. A two-compartment model was developed in the 1990s to interpret FeNO measurements with regard to the regional distribution of endogenous NO production [11-14]. According to this paradigm, FeNO is the sum of two contributions, namely, the net NO output of the airways, which are modeled as rigid tubes, and of the alveolar compartment, which is modeled as a flexible balloon [15-17]. The clinical applications of the two-compartment model are quite new. Based on the method of Tsoukias and George [11], Suri et al. [18] have recently found that alveolar, but not bronchial, NO production is elevated in a cohort of CF children with mild lung disease.

To our knowledge, the pulmonary NO exchange dynamics in $\mathrm{CF}$ adult patients have not been studied in detail so far using the two-compartment model. Our study aimed to analyze the flow-independent parameters of pulmonary NO exchange in $\mathrm{CF}$ adults compared to healthy controls by exploring the origin of the low $\mathrm{FeNO}$ previously observed in CF airways.

\section{Patients and Methods}

\section{Study Patients and Control Subjects}

Adult CF patients were recruited from the Adult CF Unit of the University Hospital Zurich, Switzerland. The diagnosis of $\mathrm{CF}$ was based on standard criteria, including each patient's CF genotype. Patients were evaluated only if they were clinically stable and without clinical signs of acute infection exacerbation and had stable lung function at the time of measurement. Chronic Pseudomonas aeruginosa infection was defined according to a recently published consensus definition, i.e., at least three positive sputum or cough swab cultures over 6 months or more with a minimum 1-month interval in between [19]. All CF patients with chronic Pseudomonas aeruginosa infection received maintenance treatment with oral azithromycin $(500 \mathrm{mg}$ three times weekly) and long-term inhalation therapy with colistin (1 million units twice daily) or TOBI ${ }^{\circledR}$ (300 mg twice daily). A subgroup of patients also were treated long-term with nebulized dornase $\alpha$ daily. No CF patient received oral or nebulized steroid treatment for at least 1 month prior to the time of assessment. None of the CF patients had a positive medical history of atopy. Skin prick tests were not performed.

Healthy control subjects recruited for the purpose of the study had no medical history of chronic illnesses, lung disease, and/or atopy and no respiratory tract infection at the time of their lung function measurements. No skin prick tests were performed in control subjects. In addition, control subjects had lung function test results [spirometry, body plethysmograph, carbon monoxide $(\mathrm{CO})$ diffusion capacity] within normal limits. Smokers were excluded from the study.

The Ethics Committee of the University Hospital Zurich approved the study. Written informed consent was obtained from all CF patients and healthy control subjects.

\section{Measurement of Exhaled Nitric Oxide and Pulmonary Function Test}

FeNO was measured according to the guidelines of the American Thoracic Society (ATS) and European Respiratory Society (ERS) with a CLD 88-NO analyzer (Eco Medics $^{\mathrm{TM}}$, Dürnten, Switzerland), using the chemiluminescent NO measuring method [3]. The analyzer was calibrated daily and readjusted before each measurement. Each subject inhaled NO-free air to total lung capacity and exhaled as long as possible at four different exhalation flow rates $\left(\mathrm{V}_{\mathrm{E}}=50,100,150\right.$, and $\left.200 \mathrm{ml} / \mathrm{s}\right)$ against a resistance of $10 \mathrm{~cm} \mathrm{H}_{2} \mathrm{O} \mathrm{L}^{-1} \mathrm{~s}^{-1}$. The breathing maneuvers were repeated three times at each exhalation flow rate. The different exhalation flow rates were obtained by using four flow restrictors designed to produce a laminar flow of the desired exhalation flow rate at a constant resistance of $10 \mathrm{~cm} \mathrm{H}_{2} \mathrm{O} \quad \mathrm{L}^{-1} \mathrm{~s}^{-1}$ for velum closure and normal breathing pressure. The exhalation flow rate was measured with an ultrasound flowmeter (Eco Medics), and biofeedback on a computer screen was used to maintain the desired flow. The exhaled NO concentration (FeNO) was registered as a function of exhaled volume (Fig. 1a), while the corresponding $\mathrm{NO}$ elimination rate $\mathrm{V}_{\mathrm{NO}}$, the product of the measured exhalation flow rate $\left(\mathrm{V}_{\mathrm{E}}\right)$ and the exhaled NO concentration $(\mathrm{FeNO})$, was recorded as a function of time (Fig. 1b). The dead space of the flowmeter was $20 \mathrm{ml}$. The end-expiratory FeNO (75-95\% of the exhalation cycle) or the corresponding $\mathrm{V}_{\mathrm{NO}}$, respectively, was utilized for calculations. Spirometry [forced expiratory volume in $1 \mathrm{~s}$ $\left(\mathrm{FEV}_{1}\right)$; forced vital capacity $\left.(\mathrm{FVC})\right]$ was performed on the same day before NO measurements. Pulmonary function tests were performed according to our laboratory protocols, which are based upon adult European Respiratory Society (ERS) standard testing [20, 21].

\section{Calculation of Alveolar NO Concentration $\left(\mathrm{C}_{\mathrm{Alv}}\right)$ and Bronchial NO flux $\left(\mathrm{J}_{\mathrm{NO}, \mathrm{Br}}\right)$}

The alveolar $\mathrm{NO}$ concentration $\left(\mathrm{C}_{\mathrm{Alv}}\right)$ and the bronchial NO flux $\left(\mathrm{J}_{\mathrm{NO}, \mathrm{Br}}\right)$ were calculated according to the model of Tsoukias and George [11] and as described in detail by Lehtimaki et al. [14, 15]. In the two-compartment model the end-expiratory FeNO at $\mathrm{V}_{\mathrm{E}} \geq 100 \mathrm{ml} / \mathrm{s}$ originates mainly from the lower respiratory tract. Therefore, in the end-expiratory phase and at $\mathrm{V}_{\mathrm{E}} \geq 100 \mathrm{ml} / \mathrm{s}$, the $\mathrm{NO}$ elimination rate $\mathrm{V}_{\mathrm{NO}}$ is a linear function of the exhalation 
healthy control

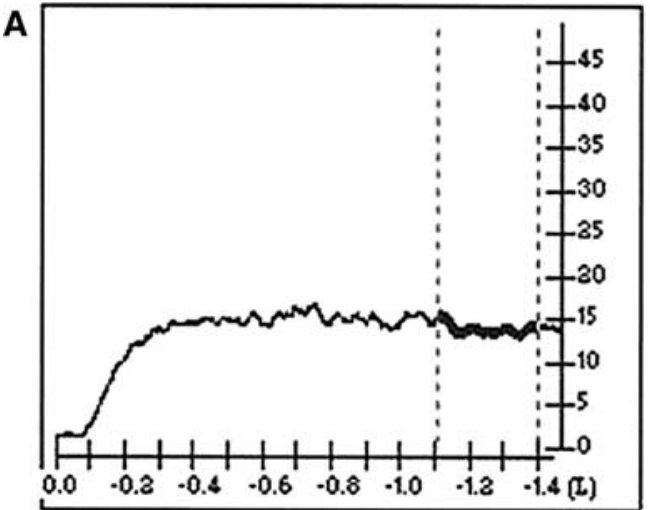

exhaled volume $(L)$

B

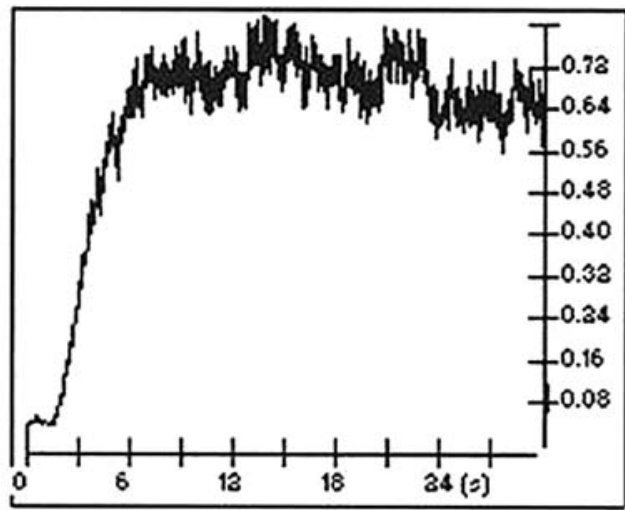

exhalation time $(\mathrm{sec})$

C

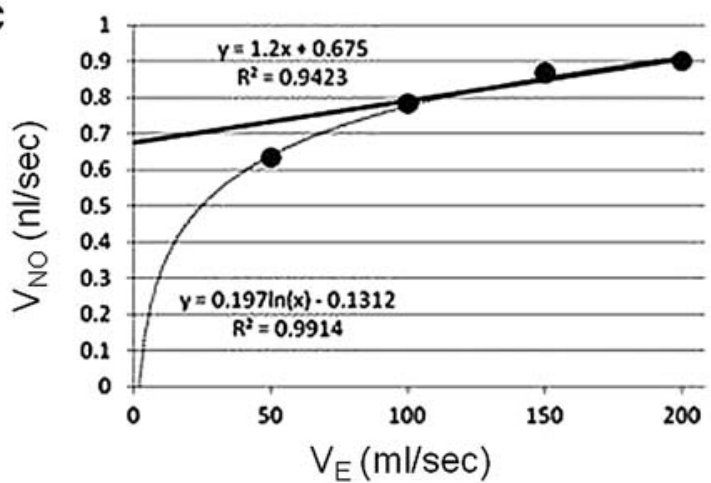

Fig. 1 Measurement of end-expiratory FeNO and calculation of flowindependent parameters. Examples of online measurements at $\mathrm{V}_{\mathrm{E}}=50 \mathrm{ml} / \mathrm{s}$ in rows $\mathrm{A}$ (FeNO vs. volume) and $\mathrm{B}\left(\mathrm{V}_{\mathrm{NO}}\right.$ vs. time $)$ for a healthy control and a CF patient show that a plateau phase is established which allows extraction of end-expiratory FeNO according

flow rate $\mathrm{V}_{\mathrm{E}}$, with the slope representing the alveolar $\mathrm{NO}$ concentration $\left(\mathrm{C}_{\mathrm{Alv}}\right)$ and a nonzero intercept approximating the bronchial NO flux $\left(\mathrm{J}_{\mathrm{NO}, \mathrm{Br}}\right)$. In Fig. 1c we show regression lines calculated from data of a healthy control cystic fibrosis patient
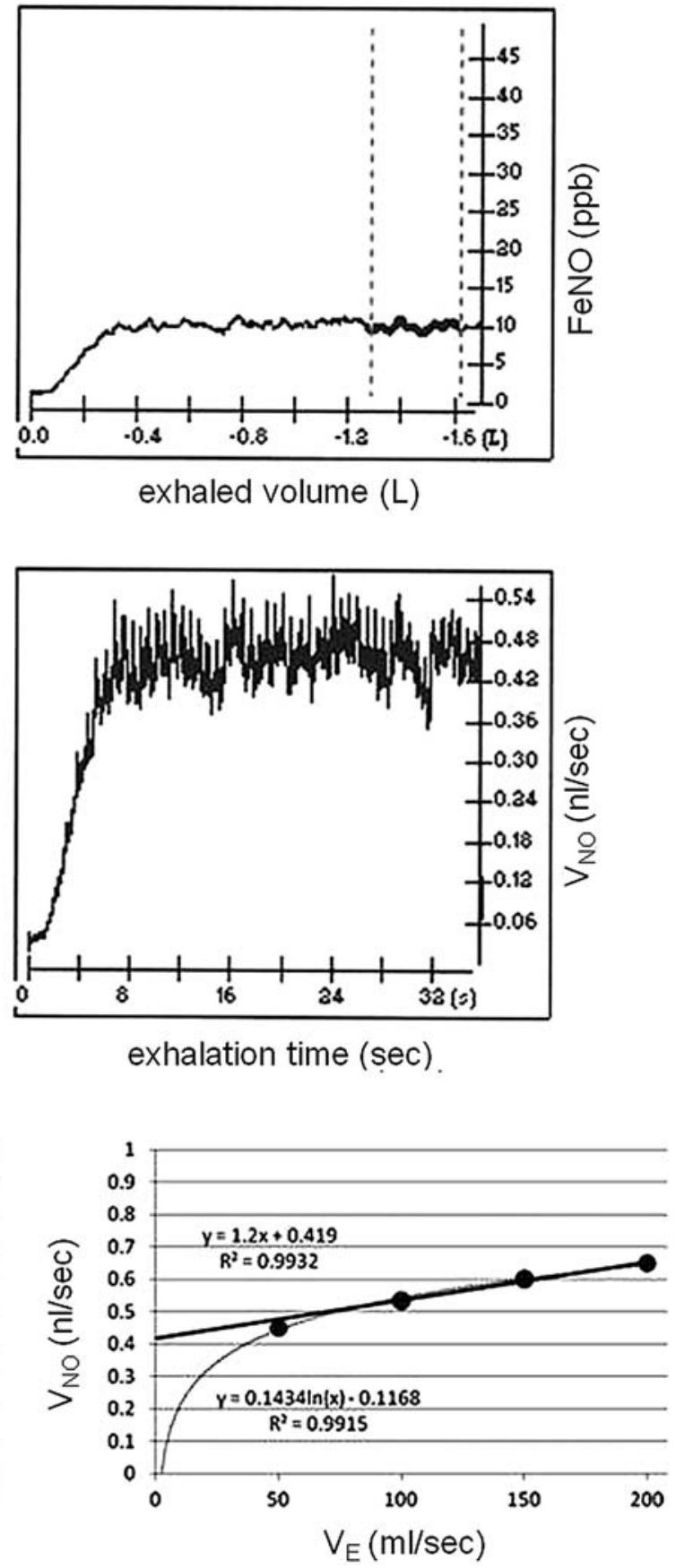

to the ATS and ERS guidelines. In row $\mathrm{C}$ the linear relationship between $\mathrm{V}_{\mathrm{NO}}$ and $\mathrm{V}_{\mathrm{E}}$ at $\mathrm{V}_{\mathrm{E}} \geq 100 \mathrm{ml} / \mathrm{s}$ is demonstrated and allows determination of the flow-independent parameters $\mathrm{C}_{\mathrm{Alv}}$ (slope) and $\mathrm{J}_{\mathrm{NO}, \mathrm{Br}}$ (intercept) according to Refs. [11] and [14]

and a CF patient. Although we also measured FeNO at $\mathrm{V}_{\mathrm{E}}=50 \mathrm{ml} / \mathrm{s}$, as recommended by the ATS and ERS guidelines, only $\mathrm{V}_{\mathrm{NO}}$ values obtained at $\mathrm{V}_{\mathrm{E}} \geq 100 \mathrm{ml} / \mathrm{s}$ were used for the calculation. 


\section{Statistics}

Values are expressed as mean and 95\% CI (confidence interval) of the mean, and, where appropriate, the median and range are presented for skewed data. The MannWhitney test was used for statistical calculation. $P<0.05$ was considered statistically significant. Correlations between bronchial obstruction $\left(\mathrm{FEV}_{1} / \mathrm{VC}\right)$ and $\mathrm{C}_{\mathrm{Alv}}$ and $\mathrm{J}_{\mathrm{NO}, \mathrm{Br}}$ were made using Spearman's rank test.

\section{Results}

Twelve adult CF patients and 20 healthy control subjects were included in the study. Patient demographics are given in Table 1. Age and gender distribution were similar in the two groups. All except of one patient were $\Delta \mathrm{F} 508$ homozygous. Patients had moderate to severe $\mathrm{CF}$ lung disease (median $\mathrm{FEV}_{1}=1.6 \mathrm{~L}$ or $48 \%$ predicted), and two-thirds were chronically infected with Pseudomonas aeruginosa. At the time of recruitment, none of the CF patients was listed for lung transplantation, even though the patients' mean age was greater than 30 years, which is higher than the mean age of 26.2 years for $\mathrm{CF}$ patients transplanted at our center in the last decade [22].

As described above, the end-expiratory FeNO (75-95\% of the exhalation cycle) at an exhalation flow rate of $\mathrm{V}_{\mathrm{E}} \geq 100 \mathrm{ml} / \mathrm{s}$ was utilized for calculations. The mean standard deviations of end-expiratory $\mathrm{FeNO}$ were $0.7 \pm 0.4,0.4 \pm 0.3,0.3 \pm 0.2$, and $0.3 \pm 0.1 \mathrm{ppb}$ for the flow rates of 50,100,150, and $200 \mathrm{ml} / \mathrm{s}$, respectively. In $\mathrm{CF}$ patients, end-expiratory FeNO was significantly lower compared to that of healthy control subjects at all exhalation flow rates (Fig. 2). There was a negative linear correlation between end-expiratory FeNO and exhalation flow

Table 1 Demographics of study population

\begin{tabular}{lll}
\hline & $\begin{array}{l}\text { Healthy } \\
\text { controls }\end{array}$ & $\begin{array}{l}\text { Cystic fibrosis } \\
\text { adults }\end{array}$ \\
\hline$N$ & 20 & 12 \\
Gender (female/male) & $11 / 9$ & $5 / 7$ \\
Age (range) (years) & $27.4(18.5-46.7)$ & $24.2(22.8-55.3)$ \\
$\mathrm{FEV}_{1}(\mathrm{~L}) *$ & $3.7(3.2-5.5)$ & $1.6(0.9-3.6)$ \\
$\mathrm{FEV}_{1}(\%$ predicted)* & $97(83-118)$ & $48(26-89)$ \\
Chronic Pseudomonas $^{*}$ & Not applicable & 8 \\
Nebuginosa infection & & \\
$\quad$ long-term therapy & Not applicable & 5 \\
\hline
\end{tabular}

$\mathrm{C}_{\mathrm{Alv}}=$ alveolar $\mathrm{NO}$ concentration; $\mathrm{J}_{\mathrm{NO}, \mathrm{Br}}=$ bronchial nitric oxide flux; $\mathrm{FEV}_{1}=$ forced expiratory volume in $1 \mathrm{~s}$

Values are expressed as median (range)

* Mann-Whitney test $P<0.0001$

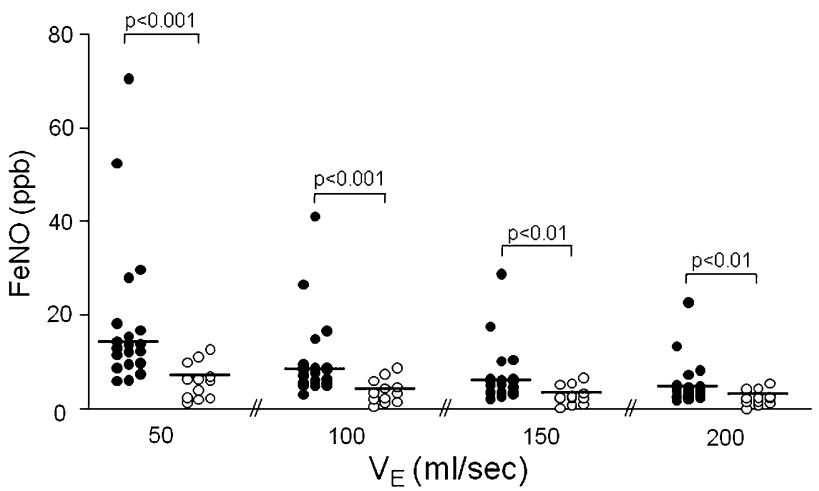

Fig. 2 End-expiratory FeNO at different fixed exhalation flow rates. The average end-expiratory FeNO from three consecutive measurements at each of four fixed exhalation flow rates $\left(\mathrm{V}_{\mathrm{E}}=50,100,150\right.$, and $200 \mathrm{ml} / \mathrm{s}$ ) is shown for each healthy control (O) and each $\mathrm{CF}$ patient $(O)$. The mean FeNO of each group is depicted as a line. Significant $(P<0.05) \quad P$ values as calculated using the MannWhitney test are given above the groups compared
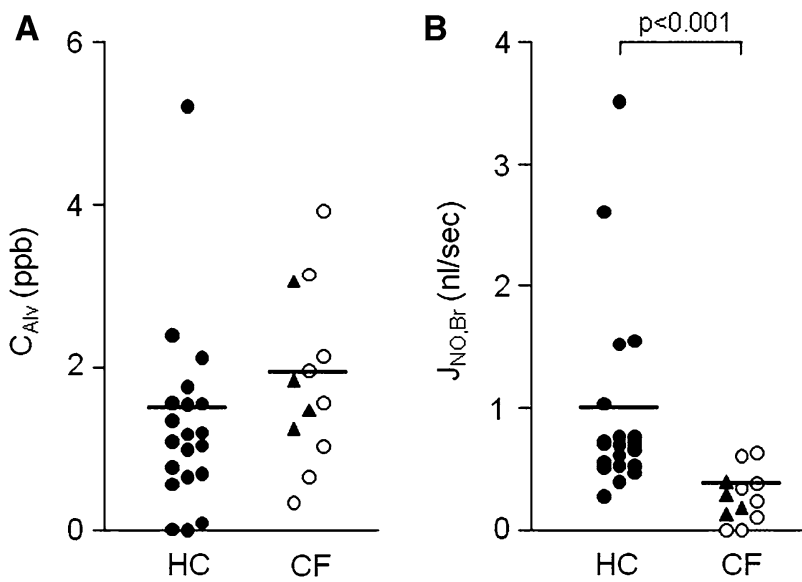

Fig. 3 Comparison of alveolar $\mathrm{NO}$ concentration $\left(\mathrm{C}_{\mathrm{Alv}}\right)$ and bronchial NO flux $\left(\mathrm{J}_{\mathrm{NO}, \mathrm{Br}}\right)$ of healthy controls and $\mathrm{CF}$ patients. Alveolar NO concentrations (a) and bronchial NO fluxes (b) as calculated from the data presented in Fig. 2 are shown for each healthy control (O) and each CF patient without $(\bigcirc)$ and with $(\mathbf{\Delta})$ chronic Pseudomonas aeruginosa infection. The mean value of each group is depicted as a line. Significant $(P<0.05) P$ values as calculated using the MannWhitney test are given above the groups compared

rates $\mathrm{V}_{\mathrm{E}} \geq 100 \mathrm{ml} / \mathrm{s}$ observed in both the CF patient group and the control groups (Figs. 1 and 2). Thus, the analytical tools of the two-compartment model can be applied to our data.

Significantly lower bronchial NO fluxes $\left(\mathrm{J}_{\mathrm{NO}, \mathrm{Br}}\right)$ were documented in $\mathrm{CF}$ adults compared to healthy controls, while alveolar $\mathrm{NO}$ concentrations $\left(\mathrm{C}_{\mathrm{Alv}}\right)$ were similar in both groups, as displayed in Fig. 3. Similarly, $\mathrm{C}_{\mathrm{Alv}}$ and $\mathrm{J}_{\mathrm{NO}, \mathrm{Br}}$ did not differ significantly between subgroups of CF patients with and without chronic Pseudomonas aeruginosa infection (Fig. 3), as well as between CF patients with and without dornase $\alpha$ inhalation, even though the number 
Fig. 4 Correlation between alveolar NO concentration $\left(\mathrm{C}_{\mathrm{Alv}}\right)$ or bronchial NO flux $\left(\mathrm{J}_{\mathrm{NO}, \mathrm{Br}}\right)$ and airway obstruction (FEV/VC). The alveolar NO concentrations $(\mathbf{a}, \mathbf{b})$ and the bronchial NO fluxes $(\mathbf{c}, \mathbf{d})$ of healthy controls $(-)$ and $\mathrm{CF}$ patients $(\bigcirc)$ were plotted against their corresponding airway obstruction as measured by spirometry immediately before FeNO measurements. Correlation was tested using Spearman's rank test
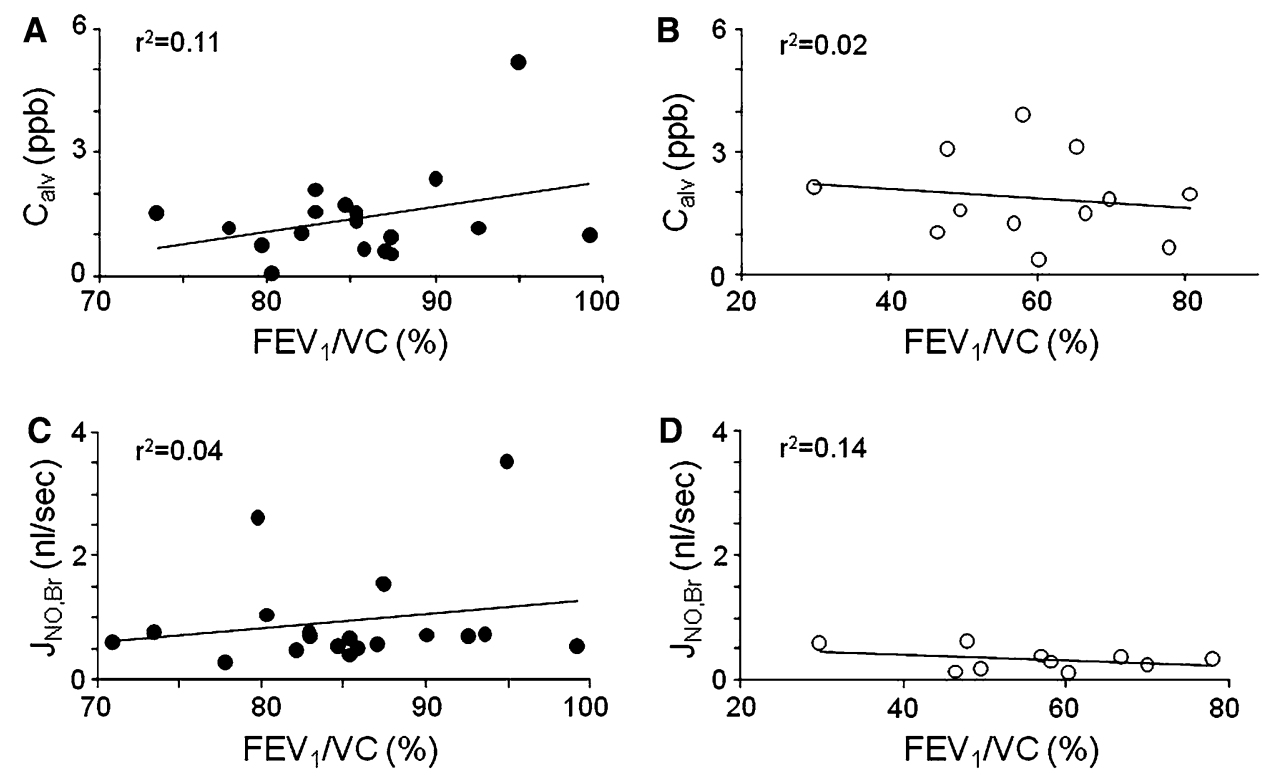

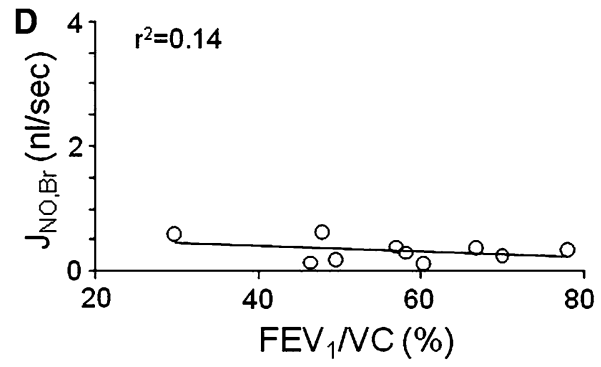

of patients in each subgroup was small [alveolar NO concentration: $1.8 \mathrm{ppb}(95 \mathrm{CI}=0.8-2.8 \mathrm{ppb})$ vs. $1.9 \mathrm{ppb}(95$ $\mathrm{CI}=0.7-3.1 \mathrm{ppb})$; bronchial NO flux: $0.426 \mathrm{nl} / \mathrm{s} \quad(95$ $\mathrm{CI}=0.175-0.676 \mathrm{nl} / \mathrm{s}) \quad$ vs. $0.229 \mathrm{nl} / \mathrm{s} \quad(95 \mathrm{CI}=0.117-$ $0.340 \mathrm{nl} / \mathrm{s})]$.

Data of flow dependency of FeNO in CF patients and healthy control subjects are given in Fig. 4. No significant correlation was detectable between bronchial obstruction $\left(\mathrm{FEV}_{1} / \mathrm{VC}\right)$ and the two independent $\mathrm{NO}$ exchange parameters $\mathrm{C}_{\mathrm{Alv}}$ and $\mathrm{J}_{\mathrm{NO}, \mathrm{Br}}$. Therefore, and after having proven the applicability of the two-compartment model to our data (Figs. 1 and 2), calculated $\mathrm{C}_{\mathrm{Alv}}$ and $\mathrm{J}_{\mathrm{NO}, \mathrm{Br}}$ values represent true parameters of $\mathrm{NO}$ exchange in the study patients and healthy controls.

\section{Discussion}

This study assessed flow-independent parameters of pulmonary NO exchange-the bronchial NO flux $\mathrm{J}_{\mathrm{NO}, \mathrm{Br}}$ and the alveolar $\mathrm{NO}$ concentration $\mathrm{C}_{\mathrm{Alv}}$-in $\mathrm{CF}$ adults and healthy controls. Our data show that bronchial NO flux is lowered in adults with moderate CF lung disease. Furthermore, alveolar NO concentrations in healthy controls and CF adults were found to be similar. Moreover, no correlation was detected between bronchial airway obstruction and alveolar or bronchial NO in CF adults.

Nitric oxide is an important signalling mediator and is involved in multiple physiological and cellular functions in the lungs. Therefore, measurements of NO concentration in exhaled air have been utilized extensively for various airway diseases, in particular, asthma but also CF [1]. Measurements of FeNO have been performed successfully in infants, children, and adults. In CF, a common inherited disease in Caucasians, chronic neutrophilic inflammation of the lungs and chronic airway infection cause progressive lung disease, the leading cause of morbidity and mortality in CF patients [23]. However, despite the chronic inflammatory character of $\mathrm{CF}$ airways disease, FeNo has been shown to be rather normal or even decreased [8-10]. The suspected causes of decreased FeNO in CF are numerous and can be summarized as follows: (1) decreased NO production secondary to impaired iNOS expression/activity or L-arginine deficiency [24-29], (2) increased bacterial, enzymatic, or chemical NO consumption [4, 30-33], and (3) slower NO diffusion through the highly viscous and abundant mucus of CF patients [24, 34].

We found similar $\mathrm{J}_{\mathrm{NO}, \mathrm{Br}}$ estimates for our $\mathrm{CF}$ patients with and without chronic Pseudomonas aeruginosa infection; therefore, NO consumption by resident bacterial pathogens or microbial enzymes seems unlikely the major cause for low bronchial NO output. In contrast, there was a trend toward higher bronchial NO flux in the subgroup of CF patients with dornase $\alpha$ treatment compared with those without dornase $\alpha$ treatment, most likely not statistically significant due to the small number of patients in this subgroup. High mucus viscosity presumably lowering NO diffusion rate and increasing net NO consumption during its passage through the mucus could thus be accountable for the low NO output in CF adults. In a recent placebo-controlled study, Grasemann et al. [35] showed that FeNO positively correlates with nebulized dornase $\alpha$ treatment in CF children. Nevertheless, based on our results and published evidence to date, it cannot be ruled out that impaired NO production also contributes to or even represents the major source of the measured deficit of exhaled NO in CF patients. 
Flow-independent parameters of NO exchange have recently been explored. Shin et al. [36] used a single-breath technique that showed similar bronchial NO fluxes $\left(\mathrm{J}_{\mathrm{NO}, \mathrm{Br}}\right)$ but lower alveolar NO concentrations $\left(\mathrm{C}_{\mathrm{alv}}\right)$ in $\mathrm{CF}$ children compared with healthy controls; however, the increase of mean NO was only weakly significant $(P=0.05)$, with a high standard deviation for $\mathrm{CF}$ patients and healthy controls. Suri et al. [18], using extended NO exchange measurements similar to the methods used in our study, reported that $\mathrm{J}_{\mathrm{NO}, \mathrm{Br}}$ did not differ between healthy children and $\mathrm{CF}$ children while $\mathrm{C}_{\mathrm{alv}}$ was higher in the patient group. The different results of the studies by Shin et al. and Suri et al. with respect to $\mathrm{C}_{\mathrm{alv}}$ are likely due to the different experimental protocols and parameter estimation methods employed, since both studies enrolled patients of similar mean age (12 vs. 13.3 years) and mild CF lung disease (mean $\mathrm{FEV}_{1} / \mathrm{FVC}$ ratios of 81 vs. 82). Our CF adult study cohort had a mean age of 30.3 years, more frequently chronic Pseudomonas aeruginosa infection, and moderate to severe lung disease. It remains to be proven if the degree of airway obstruction could explain the lowered bronchial NO fluxes in CF adults compared to the results of Shin et al. and Suri et al. Consequently, age-related features and the progression of CF lung disease might likely influence the bronchial NO flux in CF patients.

Suri et al. [18] reported that children with severe lung disease $\left(\mathrm{FEV}_{1}<40 \%\right)$ were not able to perform exhalation maneuvers at highest flows. In contrast, our adult study patients with advanced $\mathrm{CF}$ lung disease experienced no particular problems using the same technique at higher flows. Adult age might be one of the reasons for this observation.

In our study, three-fourths of the $\mathrm{CF}$ patients were chronically infected with Pseudomonas aeruginosa and therefore treated long-term with oral azithromycin according to our center's policy. Azithromycin, a macrolide antibiotic, has frequently been used in recent years as an immunomodulatory agent in advanced CF lung disease, even though its mechanism of action remains unclear [37]. In our study, however, pulmonary NO exchange dynamics in $\mathrm{CF}$ adults with and without azithromycin therapy seem not to differ significantly; however, the patient numbers of each subgroup were too small to determine the impact of chronic airway infection and long-term azithromycin therapy reliably.

Our study has limitations which are part of its crosssectional design and the small study cohort. Nevertheless, we were able to assess pulmonary NO exchange dynamics in $\mathrm{CF}$ adults, showing that $\mathrm{CF}$ patients without acute exacerbation have lower FeNO values compared to healthy controls as measured at exhalation flow rates of 50-200 ml/s. Alveolar NO concentrations are similar in CF and healthy adults, and the difference of FeNO is likely to be the result of lower bronchial NO flux. Because NO output is the sum of NO that originates from alveolar and bronchial compartments, our findings might explain the overall low values of FeNO in CF patients, probably influenced by multiple factors, including viscous mucus as a diffusion barrier for airway NO, NO consumption by bacterial enzymes, and decreased NO production.

Interestingly, four healthy controls in our study who did not have signs of atopy, asthma, or allergic rhinitis had high $\mathrm{FeNO}_{50}$ ( $\geq 30 \mathrm{ppb}$ ). However, even with their exclusion from the analysis, results remained similar and statistically significant.

The major goal of our study was a proof of principle, that is, the validity of the methodology proposed by Tsoukias and George to assess alveolar and bronchial contributions to exhaled NO in CF adults. The described method using three additional flow rates of 100, 150, and $200 \mathrm{ml} / \mathrm{s}$ can be performed easily and allows the calculation of alveolar NO concentration $\left(\mathrm{C}_{\mathrm{Alv}}\right)$ and bronchial $\mathrm{NO}$ flux $\left(\mathrm{J}_{\mathrm{NO}, \mathrm{Br}}\right)$ with a simple linear regression equation.

Further work is needed to fully understand pulmonary NO exchange dynamics in the different stages of CF lung disease across different age groups and in larger cohorts, but also compared to other chronic lung diseases such as non-CF bronchiectasis.

\section{References}

1. Grasemann H, Ratjen F (1999) Cystic fibrosis lung disease: the role of nitric oxide. Pediatr Pulmonol 28(6):442-448

2. Ricciardolo FL, Sterk PJ, Gaston B, Folkerts G (2004) Nitric oxide in health and disease of the respiratory system. Physiol Rev 84(3):731-765

3. American Thoracic Society (2005) ATS/ERS Recommendations for standardized procedures for the online, offline measurement of exhaled lower respiratory nitric oxide, nasal nitric oxide, 2005. Am J Respir Crit Care Med 171(8):912-930

4. Ricciardolo FL, Di Stefano A, Sabatini F, Folkerts G (2006) Reactive nitrogen species in the respiratory tract. Eur J Pharmacol 533(1-3):240-252

5. Barnes PJ, Belvisi MG (1993) Nitric oxide and lung disease. Thorax 48(10):1034-1043

6. Kharitonov SA, Wells AU, O'Connor BJ, Cole PJ, Hansell DM, Logan-Sinclair RB, Barnes PJ (1995) Elevated levels of exhaled nitric oxide in bronchiectasis. Am J Respir Crit Care Med 151(6): 1889-1893

7. Lundberg JO, Nordvall SL, Weitzberg E, Kollberg H, Alving K (1996) Exhaled nitric oxide in paediatric asthma and cystic fibrosis. Arch Dis Child 75(4):323-326

8. Balfour-Lynn IM, Laverty A, Dinwiddie R (1996) Reduced upper airway nitric oxide in cystic fibrosis. Arch Dis Child 75(4): 319-322

9. Grasemann H, Michler E, Wallot M, Ratjen F (1997) Decreased concentration of exhaled nitric oxide (NO) in patients with cystic fibrosis. Pediatr Pulmonol 24(3):173-177

10. De Winter-de Groot KM, van der Ent CK (2005) Nitric oxide in cystic fibrosis. J Cyst Fibros 4(Suppl 2):25-29 
11. Tsoukias NM, George SC (1998) A two-compartment model of pulmonary nitric oxide exchange dynamics. J Appl Physiol 85(2):653-666

12. Hyde RW, Geigel EJ, Olszowka AJ, Krasney JA, Forster RE 2nd, Utell MJ, Frampton MW (1997) Determination of production of nitric oxide by lower airways of humans-theory. J Appl Physiol 82(4):1290-1296

13. Pietropaoli AP, Perillo IB, Torres A, Perkins PT, Frasier LM, Utell MJ, Frampton MW, Hyde RW (1999) Simultaneous measurement of nitric oxide production by conducting and alveolar airways of humans. J Appl Physiol 87(4):1532-1542

14. Lehtimäki L, Turjanmaa V, Kankaanranta $H$, Saarelainen S, Hahtola P, Moilanen E (2000) Increased bronchial nitric oxide production in patients with asthma measured with a novel method of different exhalation flow rates. Ann Med 32(6):417-423

15. Lehtimäki L, Kankaanranta $\mathrm{H}$, Saarelainen S, Turjanmaa V, Moilanen E (2002) Increased alveolar nitric oxide concentration in asthmatic patients with nocturnal symptoms. Eur Respir J 20(4):841-845

16. George SC, Hogman M, Permutt S, Silkoff PE (2004) Modelling pulmonary nitric oxide exchange. J Appl Physiol 96(3):831-839

17. Condorelli P, Shin HW, Aledia AS, Silkoff PE, George SC (2007) A simple technique to characterize proximal and peripheral nitric oxide exchange using constant flow exhalations and an axial diffusion model. J Appl Physiol 102(1):417-425

18. Suri R, Paraskakis E, Bush A (2007) Alveolar, but not bronchial nitric oxide production is elevated in cystic fibrosis. Pediatr Pulmonol 42(12):1215-1221

19. Döring G, Conway SP, Heijerman HG, Hodson ME, Høiby N, Smyth A, Touw DJ (2000) Antibiotic therapy against Pseudomonas aeruginosa in cystic fibrosis: a European consensus. Eur Respir J 16(4):749-767

20. Roca J, Burgos F, Sunyer J, Saez M, Chinn S, Antó JM, RodríguezRoisin R, Quanjer PH, Nowak D, Burney P (1998) Reference values for forced spirometry Group of the European Community Respiratory Health Survey. Eur Respir J 11(6):1354-1362

21. Quanjer PH, Tammeling GJ, Cotes JE, Pedersen OF, Peslin R, Yernault JC (1993) Lung volumes and forced ventilatory flows. Report Working Party Standardization of Lung Function Test, European Community for Steel and Coal. Official Statement of the European Respiratory Society. Eur Respir J Suppl 16:5-40

22. Hofer M, Benden C, Inci I, Schmid C, Irani S, Speich R, Weder W, Boehler A (2009) True survival benefit of lung transplantation for cystic fibrosis patients: the Zurich experience. J Heart Lung Transplant 28(4):334-339

23. Ratjen F, Döring G (2003) Cystic fibrosis. Lancet 361(9358): 681-689

24. Thomas SR, Kharitonov SA, Scott SF, Hodson ME, Barnes PJ (2000) Nasal and exhaled nitric oxide is reduced in adult patients with cystic fibrosis and does not correlate with cystic fibrosis genotype. Chest 117(4):1085-1089

25. Kelley TJ, Drumm ML (1998) Inducible nitric oxide synthase expression is reduced in cystic fibrosis murine and human airway epithelial cells. J Clin Invest 102(6):1200-1207

26. Meng QH, Springall DR, Bishop AE, Morgan K, Evans TJ, Habib S, Gruenert DC, Gyi KM, Hodson ME, Yacoub MH, Polak JM (1998) Lack of inducible nitric oxide synthase in bronchial epithelium: a possible mechanism of susceptibility to infection in cystic fibrosis. J Pathol 184(3):323-331

27. Lane C, Knight D, Burgess S, Franklin P, Horak F, Legg J, Moeller A, Stick S (2004) Epithelial inducible nitric oxide synthase activity is the major determinant of nitric oxide concentration in exhaled breath. Thorax 59(9):757-760

28. Zheng S, Xu W, Bose S, Banerjee AK, Haque SJ, Erzurum SC (2004) Impaired nitric oxide synthase-2 signalling pathway in cystic fibrosis airway epithelium. Am J Physiol Lung Cell Mol Physiol 287(2):L374-L381

29. Moeller A, Horak F Jr, Lane C, Knight D, Kicic A, Brennan S, Franklin P, Terpolilli J, Wildhaber JH, Stick SM (2006) Inducible NO synthase expression is low in airway epithelium from young children with cystic fibrosis. Thorax 61(6):514-520

30. Gaston B, Drazen JM, Loscalzo J, Stamler JS (1994) The biology of nitrogen oxides in the airways. Am J Respir Crit Care Med 149(2 Pt 1):538-551

31. Grasemann H, Ioannidis I, Tomkiewicz RP, de Groot H, Rubin BK, Ratjen F (1998) Nitric oxide metabolites in cystic fibrosis lung disease. Arch Dis Child 78(1):49-53

32. Gaston B, Ratjen F, Vaughan JW, Malhotra NR, Canady RG, Snyder AH, Hunt JF, Gaertig S, Goldberg JB (2002) Nitrogen redox balance in the cystic fibrosis airway: effects of antipseudomonal therapy. Am J Respir Crit Care Med 165(3):387-390

33. Gaston B, Singel D, Doctor A, Stamler JS (2006) S-nitrosothiol signalling in respiratory biology. Am J Respir Crit Care Med 173(11):1186-1193

34. Högman M, Drca N, Ehrstedt C, Meriläinen P (2000) Exhaled nitric oxide partitioned into alveolar, lower airways and nasal contributions. Respir Med 94(10):985-991

35. Grasemann H, Lax H, Treseler JW, Colin AA (2004) Dornase alpha and exhaled NO in cystic fibrosis. Pediatr Pulmonol 38(5):379-385

36. Shin HW, Rose-Gottron CM, Sufi RS, Perez F, Cooper DM, Wilson AF, George SC (2002) Flow-independent nitric oxide exchange parameters in cystic fibrosis. Am J Respir Crit Care Med 165(3):349-357

37. Elizur A, Cannon CL, Ferkol TW (2008) Airway inflammation in cystic fibrosis. Chest 133(2):489-495 